БАЛЧУГОВ Аркадий Владимирович - аспирант кафедры социально-политических коммуникаций Нижегородского государственного университета им. Н.И. Лобачевского (603950, Россия, г. Нижний Новгород, ул. Ульянова, 2; islam-imomi@yandex.ru)

УСТИНКИН Сергей Васильевич - доктор исторических наук, профессор; директор Приволжского филиала ФНИСЦ РАН (603000, Россия, г. Нижний Новгород, Холодный пер., 4); начальник международной междисциплинарной научно-исследовательской лаборатории изучения мировых и региональных социально-политических процессов; научный руководитель Высшей школы международных отношений и мировой политики Нижегородского государственного лингвистического университета им. Н.А. Добролюбова (603950, Россия, г. Нижний Новгород, ул. Минина, 31a; sv.ustinkin@gmail.com) ФОМЕНКОВ Артем Александрович - доктор исторических наук, доцент, старший научный сотрудник международной междисииплинарной научно-исследовательской лаборатории изучения мировых и региональных социально-политических процессов Нижегородского государственного лингвистического университета им. Н.А. Добролюбова (603950, Россия, г. Нижний Новгород, ул. Минина, 31a; sv.ustinkin@gmail.com); artjom2310@inbox.ru)

\title{
ПОСТМОДЕРНИСТСКАЯ ТЕОРИЯ: К ВОПРОСУ О ПРИЧИНАХ УСПЕШНОСТИ
}

\begin{abstract}
Аннотация. В статье рассматриваются вопросы, связанные с «Теорией», представляющей собой прежде всего соединение радикального феминизма, квир-теории, постколониальной теории, критической расовой теории и того, что обозначается как академическая теория социальной справедливости. Авторы дополняют перечень факторов, выявленных Хелен Плакроуз и Джеймсом Линдси, делающих «Теорию» востребованной в современных реалиях, и выявляют отдельные аспекты развития науки ХХ в., повлиявшие на формирование теории.
\end{abstract}

Ключевые слова: «Теория», постмодернизм, новая этика, причины успешности, факторы

И зменения в современном мире можно характеризовать как революционные. Это касается различных сфер - экономической, политической, социальной, культурной и ряда других. Представляется даже, что масштаб изменений еще до конца не осознан. Различными проявлениями трансформаций являются и так называемая новая этика, и кризис семьи как института, и распространившееся опять же новое отношение к расовым и гендерным вопросам (включая квир-теорию), и активность движения $B L M$. Многие явления - и не только упомянутые нами - являются глубоко переплетенными между собой частями реальности, которая прежде всего получила распространение в странах Запада. Впрочем, Россия не может быть полностью в стороне от различных проявлений такого рода новшеств.

Подчеркнем, что в данной статье нет попыток обозначить новую реальность как сугубо деструктивную, противопоставляющую себя традиционным ценностям, мировым религиям и т.п., равно как и не дается однозначный ответ, каким образом можно преодолеть негативные последствия внедрения, например, новой этики. Отметим также, что наша статья не состоялась бы без крайне интересной монографии Хелен Плакроуз и Джеймса Линдси «Циничные теории. Как все стали спорить о расе, гендере и идентичности, и что в этом плохого» (2022). Мы постарались выделить еще несколько важных факторов, без которых то, что они именуют «Теорией» (мы вслед за ними также пишем ее с большой буквы), не могла бы сейчас иметь столь большую значимость - как минимум, в западном мире.

Отметим, что, не будучи марксистами, мы вполне разделяем идею, что «теория становится материальной силой, как только она овладевает массами» 
[Маркс 1954: 422]. То есть, во-первых, мы признаем, что «Теория», представляющая собой прежде всего соединение радикального феминизма, квиртеории, постколониальной теории, критической расовой теории и того, что обозначается как академическая теория социальной справедливости, является развитием ряда философских идей (в т.ч. и тех, которые вряд ли следует оценивать негативно!) и практик. Во-вторых, мы придерживаемся мнения, что та или иная доктрина может изначально быть лишь игрой ума политического (или экономического) маргинального мыслителя, но впоследствии же станет весьма популярной. Причины популярности идей следует искать прежде всего в наличии политического субъекта, который возьмет эти идеи на вооружение. Как вариант, действительно появится массовая социальная группа, которая будет считать, что та или иная политическая доктрина выражает ее интересы. Яркий пример: идеи Т. Мора и Т. Кампанеллы на момент написания их трудов были игрой ума интеллектуалов, но не имели шансов стать популярными, и уж тем более - руководством к действию уже хотя бы по причине отсутствия субъектности той социальной группы, которую бы эти идеи воодушевили. В-третьих, резюмируя вышесказанное, подчеркнем, что «Теория» не есть случайность, но является вполне закономерным развитием философской мысли, а также государства, общества и технологий в XXI столетии.

Пункт первый: «Теория» могла появиться только в мире, характерной чертой которого является глобализация. Из выделяемых Г.А. Дроботом признаков глобализации для нас в контексте данной статьи наиболее значимыми являются следующие: «объективное повышение проницаемости межгосударственных перегородок, выражающееся в феноменах “преодоления границ” и “экономического гражданства”; резкое возрастание объемов и интенсивности трансгосударственных, транснациональных перетоков капиталов, информации, услуг и человеческих ресурсов <...> [а также] формирование виртуального пространства электроннокоммуникационного общения» [Дробот 2008: 108 ].

Пункт второй: «Теория» по своему происхождению является проявлением постмодерна. Об этом как раз немало написано Хелен Плакроуз и Джеймсом Линдси [Плакроуз, Линдси 2022: 30-38].

Пункт третий, он же важнейший постмодернистский принцип: радикальный скептицизм в возможности получения объективного знания. Признаем, что отчасти такое понимание было подготовлено многими мыслителями прошлого столетия. Упомянем П. Фейерабенда (напомним, что, по его мнению, «выигрывает конкурентную борьбу теория, по тем или иным причинам оказавшаяся созвучной социально-политической обстановке» [История... 2016: 164]) и Т. Куна (он признавал, что «идентификация факта как аномалии не диктуется самим фактом; аномалией признает факт научное сообщество» [История... 2016: 153]). В какой-то мере научное сообщество, подобно Сократу, признало, что «оно знает, что ничего не знает», а постмодернисты, по сути, довели этот постулат до абсурда.

Пункт четвертый, опять же важнейший постмодернистский принцип: общество состоит из структур власти и иерархий, определяющих, что и как допустимо знать. В данном случае имеет место доведение до абсурда идей М. Фуко, считавшего, что власть и знания тесно переплетены. Смотрим выше цитату об идеях П. Фейерабенда и признаем и тут наличие рационального звена: в самом деле, к примеру, в средневековой Европе геоцентрическая картина мира поддерживалась не в последнюю очередь благодаря власти. Или возьмем более близкий сюжет: норманизм доминировал в досоветской России, отвечая представлениям тогдашней российской элиты, а антинорманизм победил при И.В. Сталине, когда был взят курс на построение социализма в одной стране 
и, соответственно, тезис о вековой отсталости страны стал куда как менее востребованным. Сюда же отнесем и тезис об относительности моральных норм. Во всяком случае, очевиден факт трансформации многих представлений о том, что есть «хорошо» и что есть «плохо» в разные эпохи (на нашей памяти одни и те же люди в советские годы говорили об аморальности и преступности занятия бизнесом - сиречь спекуляцией, а затем, уже в постсоветский период, наоборот, о том, как хорошо и морально заниматься бизнесом).

Пункт пятый, он же один из основных сюжетов постмодернизма: размывание грании. В данном случае речь идет прежде всего о скептицизме, во многом опять же доведенном до абсурда. Впрочем, признаем, что отсутствие размывания границ в глобальном мире вряд ли возможно.

Пункт шестой - тоже один из основных сюжетов постмодернизма: власть языка. И тут отметим, что в ХХ в. было сделано очень много для изучения феномена языка и связи последнего с властью. Признаем, что язык развивается не в последнюю очередь под влиянием социальных групп, обладающих влиянием. Не случайно «великая криминальная революция» (термин С.С. Говорухина [Говорухин 1993]) привела к легитимации российского криминального жаргона, результатом чего стало активное использование соответствующей сниженной лексики представителями политической элиты и т.п. [Калакина и др. 2019: 183]. Для сравнения: выражения, применяемые в общении представителями многих отечественных субкультур, так в рамках этих субкультур и остались по причине малой влиятельности последних.

Пункт седьмой: культурный релятивизм. Тут опять же все довольно-таки ясно и понятно. Об отсутствии универсального пути развития писали и Н.Я. Данилевский, и А.Дж. Тойнби. Главное, не доводить до абсурда эти идеи.

Пункт восьмой: утрата индивидуального и универсального. В принципе тоже вырос из научного интереса к изучению различных групп и их ценностей [Плакроуз, Линдси 2022: 36].

А теперь хотелось бы добавить еще пункты, которые не были прямо упомянуты Хелен Плакроуз и Джеймсом Линдси, но без которых «Теория» не имела бы шансов на успех в современном мире. Итак, прежде всего укажем, что «Теория» имеет шансы на успех только при условии высокого и даже весьма высокого уровня жизни, включая стандарты личной безопасности. В противном случае группы, могущие объективно выиграть от претворения «Теории» в жизнь, крайне немногочисленны. Авторы, например, убеждены, что в реалиях советского быта эпохи перестройки с присущим тому дефицитом товаров и услуг феминистское движение - не только радикальное, но и любое - было обречено на провал уже хотя бы по причине того, что женщин волновали проблемы выживания, а не борьбы за свои женские, попранные мужчинами права.

Следующий важный пункт - это высокая степень свободы. Сюда причислим прежде всего гражданские права и свободы, равно как и механизм отстаивания таковых - все это весьма развито в странах Запада. Но ничуть не менее важно и развитие Всемирной паутины. Ее действительно нельзя контролировать полностью. Однако свобода, как показывает практика, имеет и высокую цену. Наряду с возможностью пользоваться достижениями мировой культуры и новых технологий, Интернет предоставил возможность для распространения контента с крайне низким интеллектуальным содержанием и откровенно экстремистских и мизантропических идей. Отсутствие цензуры приводит не только к появлению новых талантливых людей, сумевших заявить о себе миру, но также и к тому, что кумирами миллионов могут стать люди с весьма неоднозначной репутацией. 
Далее, пункт, напрямую связанный с предыдущим, - цифровизация. Отметим, что сама по себе цифровизация есть несомненное благо для человечества. Однако свобода пользования рядом новых возможностей, связанных с цифровизацией, ведет к переменам, которые а) в полном объеме еще не изучены и б) ведут к социальным изменениям.

Успешность «Теории» в странах Запада (подчеркнем, что не во всех) есть не что иное, как следствие синергетического эффекта ввиду наличия всех без исключения перечисленных нами причин, равно как и совокупно довольно немалочисленных социальных групп, могущих извлечь прямую выгоду от реализации положения «Теории» в жизнь.

\section{Список литературы}

Говорухин С.С. 1993. Великая криминальная революция. М.: Андреевский флаг. $126 \mathrm{c}$.

Дробот Г.А. 2008. Глобализация: Понятие, этапы, противоречия, оценки. Социально-гуманитарные знания. № 2. С. 105-127.

История и философия науки: учебник для вузов (под. общ. ред. А.С. Мамзина, Е.Ю. Сиверцева). 2-е изд., перераб. и доп. 2016. М.: Юрайт. 360 с.

Калакина К.А., Насонов Д.С., Пахомова Е.А., Фоменков А.А. 2019. Новые медиа и новые опасности: О российском политизированном блоггинге. Культура, образование и искусство: партнерство семьи и дополнительного образования в формировании профессиональных ценностей: сборник статей по материалам всероссийской научно-практической конференции. Нижний Новгород: Изд-во НГПУ им. Козьмы Минина. С. 181-184.

Маркс К. 1954. К критике гегелевской философии права. Введение. - Маркс К., Энгельс Ф. Сочинения. М.: Издательство политической литературы. 669 с.

Плакроуз Х., Линдси Д. 2022. Циничные теории. Как все стали спорить о расе, гендере и идентичности, и что в этом плохого (пер. с англ. Д. Виноградова). М.: Individuum. $384 \mathrm{c}$.

BALCHUGOV Arkadiy Vladimirovich, postgraduate student of the Chair of Social and Political Communications, National Research Lobachevsky State University of Nizhny Novgorod (2 Ul'yanova St, Nizhny Novgorod, Russia, 603950, islam-imomi@yandex.ru)

USTINKIN Sergey Vasilyevich, Dr.Sci. (Hist.), Professor; Director of the Volga Branch of the Federal Center of Theoretical and Applied Sociology, Russian Academy of Sciences (4 Holodny Lane, Nizhny Novgorod, Russia, 603000); Head of the International Cross-Disciplinary Laboratory for Studies of Global and Regional Sociopolitical Processes, Scientific Director of the Higher School of International Relations and World Politics, Dobroljubov State Linguistics University of Nizhny Novgorod (31a Minina St, Nizhny Novgorod, Russia, 603155; sv.ustinkin@gmail.com)

FOMENKOV Artyom Aleksandrovich, Dr.Sci. (Hist.), Associate Professor; Senior Researcher at the International Cross-Disciplinary Laboratory for Studies of Global and Regional Sociopolitical Processes, Dobroljubov State Linguistics University of Nizhny Novgorod (31a Minina St, Nizhny Novgorod, Russia, 603155; artjom2310@inbox.ru)

\section{POSTMODERN THEORY: TO THE QUESTION OF THE REASONS FOR SUCCESS}

\footnotetext{
Abstract. The article deals with issues related to the Theory, which is primarily a combination of radical feminism, queer theory, postcolonial theory, critical racial theory and what is designated as an academic theory of social justice. The authors supplement the list of factors identified by Helen Pluckrose and James Lindsay that make the theory in demand in modern
} 
realities. The paper reveals certain aspects of the development of science of the $20^{\text {th }}$ century that influenced the formation of the Theory.

Keywords: Theory, postmodernism, new ethics, reasons for success, factors

ПЕТРОВ Вячеслав Константинович - кандидат философских наук, главный редактор сайта «Политическое образование», научный руководитель Школы молодого этнополитолога, член Экспертного совета при Федеральном агентстве по делам национальностей (vp230754@таil.ru) ПЕТРОВА Марина Юрьевна - кандидат психологических наук, заместитель главного редактора сайта «Политическое образование», эксперт Школь молодого этнополитолога (тр210260@ mail.ru)

\section{РУССКИЙ ЯЗЫК КАК ОСНОВА РУССКОЙ АНАЛИТИКИ}

Аннотация. В современных исследованиях, посвященных отечественной аналитике, полностью отсутствуют собственные подходы, соответствующие русской ментальности и русской аналитической традиции. В статье высказывается предположение, что специфическая русская аналитика существует, и доказывается этот тезис исходя из своеобразия и уникальности русского языка (в т.ч. философского). Авторы приходят к выводу, что русская аналитика начинается с овладения всем богатством русского языка и предлагают существенно дополнить учебные программы подготовки аналитиков изучением русской философской традиции, функционального языкознания и психолингвистики.

Ключевые слова: русская философская традиция, специфическая русская аналитика, своеобразие и уникальность русского языка, учебные программы подготовки аналитиков

Сегодня, когда речь заходит об отечественной аналитике, все внимание сосредоточивается на ее институционализации, координации и встраивании в международное интеллектуальное сообщество. Этому посвящен целый ряд исследований, в которых эти вопросы раскрываются с разной степенью глубины и детализации. Единственное, что объединяет все эти работы, - отсутствие даже намека на выработку собственных подходов, соответствующих русской ментальности и русской аналитической традиции.

Возьмем, к примеру, аналитический доклад Экспертного института социальных исследований «Интеллектуальная экспансия. Российские “фабрики мысли": возможности влияния в международном экспертно-политическом пространстве» ${ }^{1}$. В нем подчеркивается, что «организация и деятельность таких центров исторически обусловлена спецификой страны, ее традиций науки и образования, принципами научного познания, разделяемыми в интеллектуальной элите общества... Для России, пережившей драматические сломы государственности на протяжении XX века, представляется крайне важным учет особенностей работы таких структур за рубежом и использование собственных наработок, имеющихся по широкому спектру исследовательских направлений (политические институты и процессы, международные отношения и мировая политика, зарубежное и отечественное регионоведение, конфликтология и др.)». Если бы не это упоминание России во введении доклада, вообще непо-

1 https://eisr.ru/projects-and-researches/intellektualnaya-ekspansiya-rossiyskie-fabriki-myslivozmozhnosti-vliyaniya-v-mezhdunarodnom-ekspert/ (проверено 16.01.2022). 